\title{
The effect of density and height of vegetation in open channel on the Manning's coefficient
}

\author{
Maimun Rizalihadi ${ }^{*}$ \\ ${ }^{1}$ Civil Engineering Department, Syiah Kuala University, J1. Syech Abdurrauf No. 7, Darussalam, Banda Aceh 23111, Indonesia.
}

\begin{abstract}
One of an important parameter to study water flow in channel is Manning's coefficient (n). This coefficient is produced not only from material forming the channel, but also due to presence of vegetation in channel. The aim of research is to study the effect of vegetation density and height on Coefficient of Manning in open channel. The study was conducted in open channel with $15.5 \mathrm{~m}$ long, $0.5 \mathrm{~m}$ wide and $1.0 \mathrm{~m}$ high. At the center of $3 \mathrm{~m}$ long of channel is planted with Sweet flag (Acorus calamus). The impact of various densities and heights of sweet flag were examined using fixed discharge to measure velocity and slope energy. Coefficient of Manning was obtained using Manning's equation. Statistical analysis of variance with significance level of 0.05 was adopted to evaluate the effect of variables. The result showed that increasing density and height of Sweet flag make decreasing velocity and increasing Coefficient of Manning to be $0,043-0,064$, or 1.40-2.10 times compared to un-vegetated channel $\left(\mathrm{n}_{0}=0.031\right)$. Based on statistical analysis, it is found that $F_{\text {calc }}=15.646$ and 16.928 for vegetation density and height respectively, which is larger than $F_{S t a t}=2,603$. It can be concluded that density and height of vegetation significantly influence on Coefficient of Manning.
\end{abstract}

\section{Introduction}

One of an important parameter to study water flow in channel is Coefficient of Manning (n). This coefficient is produced not only from material forming the channel, but also any obstacle including vegetation grown in channel.

In one hand, the vegetation which grows in the channel can protect the channel stable from scouring, but on the other hand, the presence of vegetations in the channel can increase the flow resistance making increase the loss of energy in the channel. Many prior researchers like $[2-5,10]$, have studied concerning with flow resistance due to vegetation with different characteristics of vegetation in the channel. All studies agreed that the presence of vegetation in the channel can increase the values of Coefficient of Manning as effect of increasing flow resistance. But the study of flow resistance due to the vegetation is very complicated since there are many different kinds and type of plants changing in relation to time of growing, and may be definitely different from one place to another place. These inhomogeneous character of the vegetation in the field make difficulty to figure out the accurate prediction of the channel's roughness in a model of the equation. Because of its importance, so it is necessary to do further research by including for different treatments and type of vegetation growing in the channel to obtain the more reliable approach in general application of model.

The objectives of this research is to study and to test statistically the effects of density and height of Sweet flag (Acorus Calamus) on Coefficient of Manning

The study was laboratory experimental research by using Jeringau or Sweet flag (Acorus Calamus) planted in the channel, as prior research done by [7-8], but different treatment.

[7] studied the influence of height variation of vegetation on flow resistance, where the results showed that there was an increase in flow resistance in the channel which was indicated by an increase in the Manning coefficient (nv) ranging from 0.01-0.031 due to an increase in plant height. Meanwhile, [8] studied the influence of density variation of vegetation on flow resistance in the channel, and gave the results of an increase in the Manning coefficient (nv) as an increase in vegetation density between $0.013-0.031$. This shows that both studies provide significant manning coefficient values due to the influence of vegetation height and density even in separate conditions

Because of these effects, then the main object of this research is to describe the Coefficient of Manning by combining both effect of density and height of vegetation.

\footnotetext{
* Corresponding author: maimunrizalihadi@unsyiah.ac.id
} 


\section{Literature review}

\subsection{Manning's Equation}

The Manning's equation is one of well-known equation which is often used in hydraulics of open channel. This formula is a function of the dimension of channel, channel slope and roughness of channel [1]. The equation of Manning Equation, which is commonly used to calculate mean velocities in open-channel is formulated as below.

$$
\mathrm{V}=\frac{1}{\mathrm{n}} \mathrm{R}^{2 / 3} \mathrm{~S}^{1 / 2}
$$

where; $\mathrm{n}$ is the channel roughness symbolled by Coefficient of Manning, $\mathrm{V}$ is mean velocity in $\mathrm{m} / \mathrm{s}, \mathrm{R}$ is hydraulic radius in $\mathrm{m}$, and $\mathrm{S}$ is slope of water surface.

The mean velocity is dependent on the amount of friction between the water and the channel so called channel's roughness which is correlated with the Coefficient of Manning (n). This coefficient contributes to turbulence, which dissipates energy, increase flow resistance and reduces flow velocity. The Coefficient of Manning (n) as in the Equations 1 is mainly produced from the roughness of materials which form channels. But, naturally the flow resistance is caused by many factors, therefore actually Coefficient of Manning should be determined using Equation 2.

$$
n=\left(n_{0}+n_{1}+n_{2}+n_{3}+n_{4}\right) m_{5}
$$

where; $\mathrm{n}_{0}$ is the base roughness of material forming the channel, $\mathrm{n}_{1}$ is the irregularity of channel surface, $\mathrm{n}_{2}$ is irregularity of channel section, $\mathrm{n}_{3}$ is the structure hindrance, $\mathrm{n}_{4}$ is the vegetation hindrance and $\mathrm{m}_{5}$ is correction factor for meandering channel alignment.

The coefficients of $\mathrm{n}_{1}, \mathrm{n}_{2}, \mathrm{n}_{3}$ are assumed not significant and can be neglected, so Equation 2 in some cases is merely influenced by the roughness of material which form channel and due to vegetation [1], so can be written as in Equation 3.

$$
\mathrm{n}=\mathrm{n}_{0}+\mathrm{n}_{4}
$$

In addition, [3] has completely published the values of Coefficient of Manning for thickets and woody vegetation. For these types and characteristics of vegetation [3] gave specific formula to estimate the Coefficient of Manning as in Equation 4.

$$
\mathrm{n}=\mathrm{n}_{0} \sqrt{1+\left(\frac{C_{D} \sum A_{i}}{2 g A L}\right)\left(\frac{K n}{n_{0}}\right)^{2}\left(\frac{A}{P}\right)^{\frac{4}{3}}}
$$

where; $A_{i}$ is individual vegetated area in sq. $\mathrm{m}, \mathrm{A}$ is channel area in sq. $m, C_{D}$ is drag coefficient of vegetation, $g$ is gravity in $\mathrm{m} / \mathrm{s}^{2}, \mathrm{~K}_{\mathrm{n}}$ is conversion unit, $\mathrm{L}$ is length of channel in meter, $\mathrm{n}_{0}$ is roughness of material which form the channel and $\mathrm{P}$ is wetted perimeter in meter.

\section{Experimental designs and methods}

The procedure of research method which is applied in this research is the same as and follows the previous research done by [6-9]. The difference is only on placing vegetation treatments and method of data analysis. Steps of methodology in this research is described below.

\subsection{Preparation and measurements}

The preparation stage of research is to provide the channel, vegetation and equipment. In this research, the channel used is a wall glass flume with dimension of 15.50-meter-long, 0.50-meter-wide and 1.00-meter high. Thompson water gate is constructed at upstream of channel to control the discharge and water depth remain $45 \mathrm{~cm}$. At 3-meter-long center part of channel is planted with Sweet flag (Acorus calamus). Type of sweet flag used in the research is shown in Figure 1. The equipment used in the research are Micro currentmeter (KENEK VO-301and Model VOT2-100-05) to measure the velocity and Point gauge (Armfield serial No. 6449-14) to measure the water profile.

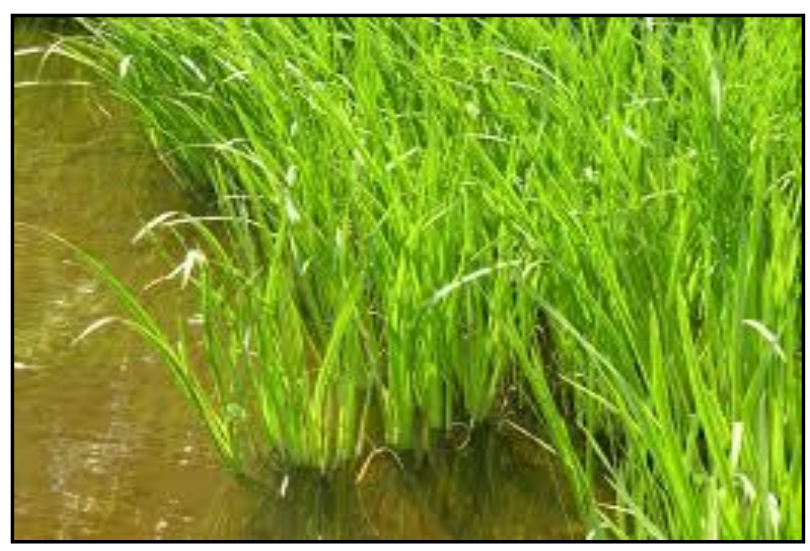

Fig. 1. Sweet flag (Acorus Calamus) growing in the field

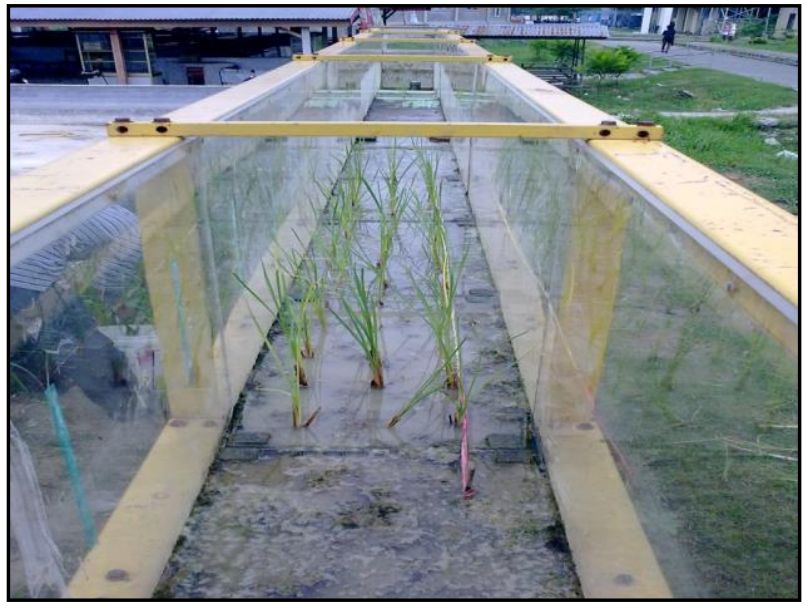

Fig. 2. Sweet flag (Acorus Calamus) placed in the flume

The vegetation is planted at 3-meter-long of center part of channel with a density of $0,6,12,18,30$ and 42 $\mathrm{veg} / \mathrm{m}^{2}$ and every height of vegetation $\left(\mathrm{H}_{\mathrm{v}}\right)$ of $0,9,27$, 36,45 and $54 \mathrm{~cm}$. The position of vegetation with all 
variations density and height of vegetation in the channel can be seen clearly in Figure 2, 3 and 4.

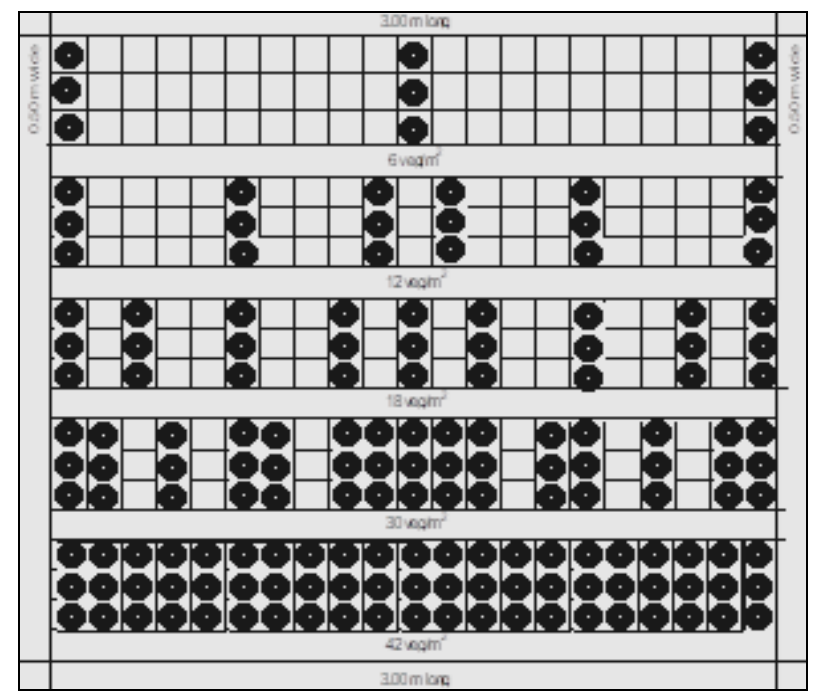

Fig. 3. Top view of vegetation arrangements in the channel

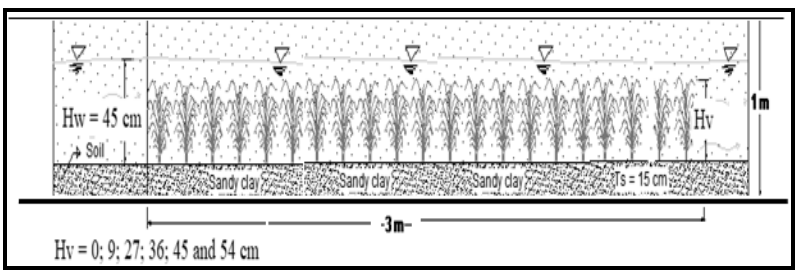

Fig. 4. Side view of vegetation arrangements for density 42 $\mathrm{veg} / \mathrm{m}^{2}$ in the channel

The flow was run on the basis of variations of density and height of vegetation to measure the velocity and level of water surface at upstream $\left(\mathrm{V}_{\mathrm{u}}\right.$ and $\left.\mathrm{H}_{\mathrm{u}}\right)$ and at downstream of flume $\left(\mathrm{V}_{\mathrm{d}}\right.$ and $\left.\mathrm{H}_{\mathrm{d}}\right)$. The velocity was measured at bottom, $0.2 \mathrm{~h}, 0,6 \mathrm{~h}, 0.8 \mathrm{~h}$ and water surface to obtain the profile of velocity distribution. Completely, all 36 series of measurements of $\mathrm{V}_{\mathrm{u}}, \mathrm{H}_{\mathrm{u}}, \mathrm{V}_{\mathrm{d}}$ and $\mathrm{H}_{\mathrm{d}}$ is tabulated in the Table 1.

Table 1. Series of measurements

\begin{tabular}{|c|c|c|c|c|c|c|}
\hline \multirow{2}{*}{$\begin{array}{c}\text { Height of } \\
\text { Vegetatio } \\
\mathrm{n}(\mathrm{Hv}) \\
\text { in } \mathrm{cm}\end{array}$} & \multicolumn{6}{|c|}{$\begin{array}{l}\text { Density of Vegetation }\left(V_{D}\right) \\
\text { in vegetation per } m^{2}\end{array}$} \\
\hline & 0 & 6 & 12 & 18 & 30 & 42 \\
\hline 0 & $\begin{array}{c}\left(H_{u}, H_{d,},\right. \\
V_{u}, \\
\left.V_{d}\right)_{0,0}\end{array}$ & $\begin{array}{c}H_{u}, H_{d}, \\
V_{u}, \\
\left.V_{d}\right)_{0,6}\end{array}$ & $\begin{array}{c}\left(H_{u}, H_{d},\right. \\
V_{u}, \\
\left.V_{d}\right)_{0,12}\end{array}$ & $\begin{array}{c}\left(H_{u}, H_{d,},\right. \\
V_{u}, \\
\left.V_{d}\right)_{0,18}\end{array}$ & $\begin{array}{c}\left(H_{u}, H_{d},\right. \\
V_{u}, \\
\left.V_{d}\right)_{0,30}\end{array}$ & $\begin{array}{c}\left(H_{u}, H_{d},\right. \\
V_{u}, \\
\left.V_{d}\right)_{0,42}\end{array}$ \\
\hline 9 & $\begin{array}{c}\left(H_{u}, H_{d},\right. \\
V_{u}, \\
\left.V_{d}\right)_{g, o}\end{array}$ & $\begin{array}{c}\left(H_{u}, H_{d},\right. \\
V_{u} \\
\left.V_{d}\right)_{9,6}\end{array}$ & $\begin{array}{c}\left(H_{u}, H_{d},\right. \\
V_{u}, \\
\left.V_{d}\right)_{g, 12}\end{array}$ & $\begin{array}{c}\left(H_{u}, H_{d,},\right. \\
V_{u}, \\
\left.V_{d}\right)_{g, 18}\end{array}$ & $\begin{array}{c}\left(H_{u}, H_{d},\right. \\
V_{u}, \\
\left.V_{d}\right)_{9,30}\end{array}$ & $\begin{array}{c}\left(H_{u}, H_{d},\right. \\
V_{u}, \\
\left.V_{d}\right)_{9,42}\end{array}$ \\
\hline 27 & $\begin{array}{c}\left(H_{u}, H_{d,},\right. \\
V_{u}, \\
\left.V_{d}\right)_{27,0}\end{array}$ & $\begin{array}{c}\left(H_{u}, H_{d},\right. \\
V_{u}, \\
\left.V_{d}\right)_{27,6}\end{array}$ & $\begin{array}{c}\left(H_{u}, H_{d},\right. \\
V_{u}, \\
\left.V_{d}\right)_{27,12}\end{array}$ & $\begin{array}{c}\left(H_{u}, H_{d},\right. \\
V_{u}, \\
\left.V_{d}\right)_{27,18}\end{array}$ & $\begin{array}{c}\left(H_{u}, H_{d},\right. \\
V_{u}, \\
\left.V_{d}\right)_{27,30}\end{array}$ & $\begin{array}{c}\left(H_{u}, H_{d},\right. \\
V_{u}, \\
\left.V_{d}\right)_{27,42}\end{array}$ \\
\hline 36 & $\begin{array}{c}\left(H_{u}, H_{d},\right. \\
V_{u}, \\
\left.V_{d}\right)_{36,0}\end{array}$ & $\begin{array}{c}\left(H_{u}, H_{d,},\right. \\
V_{u}, \\
\left.V_{d}\right)_{36,6}\end{array}$ & $\begin{array}{c}\left(H_{u}, H_{d},\right. \\
V_{u}, \\
\left.V_{d}\right)_{36,12}\end{array}$ & $\begin{array}{c}\left(H_{u}, H_{d},\right. \\
V_{u}, \\
\left.V_{d}\right)_{36,18}\end{array}$ & $\begin{array}{c}\left(H_{u}, H_{d},\right. \\
V_{u}, \\
\left.V_{d}\right)_{36,30}\end{array}$ & $\begin{array}{c}\left(H_{u}, H_{d},\right. \\
V_{u}, \\
\left.V_{d}\right)_{36,42}\end{array}$ \\
\hline 45 & $\begin{array}{c}\left(H_{u,},\right. \\
H_{d}, V_{u}, \\
\left.V_{d}\right)_{45,0}\end{array}$ & $\begin{array}{c}\left(H_{u,},\right. \\
H_{d}, V_{u}, \\
\left.V_{d}\right)_{45,6}\end{array}$ & $\begin{array}{c}\left(H_{u},\right. \\
H_{d}, V_{u}, \\
\left.V_{d}\right)_{45,12}\end{array}$ & $\begin{array}{c}\left(H_{u,},\right. \\
H_{d}, V_{u}, \\
\left.V_{d}\right)_{45,18}\end{array}$ & $\begin{array}{c}\left(H_{u},\right. \\
H_{d}, V_{u}, \\
\left.V_{d}\right)_{45,30}\end{array}$ & $\begin{array}{c}\left(H_{u},\right. \\
H_{d}, V_{u}, \\
\left.V_{d}\right)_{45,42}\end{array}$ \\
\hline
\end{tabular}

\begin{tabular}{|c|c|c|c|c|c|c|}
\hline \multirow{3}{*}{54} & $\left(H_{u}, H_{d,}\right.$, & $\left(H_{u}, H_{d,}\right.$, & $\left(H_{u}, H_{d,}\right.$ & $\left(H_{u}, H_{d,}\right.$ & $\left(H_{u}, H_{d,}\right.$ & $\left(H_{u}, H_{d,}\right.$ \\
& $V_{u}$, & $V_{u}$, & $V_{u}$, & $V_{u}$, & $V_{u}$, & $V_{u}$, \\
& $\left.V_{d}\right)_{54,0}$ & $\left.V_{d}\right)_{54,6}$ & $\left.V_{d}\right)_{54,12}$ & $\left.V_{d}\right)_{54,18}$ & $\left.V_{d}\right)_{54,30}$ & $\left.V_{d}\right)_{54,42}$ \\
\hline
\end{tabular}

\subsection{Data analysis}

\subsubsection{Mean velocity}

Mean velocity is obtained using Equation 5 below. This velocity is analysed using 10 points method based on the velocity at the point of water surface, $0.2 \mathrm{~h}, 0.6 \mathrm{~h}$, $0.8 \mathrm{~h}$ and bottom of channel.

$$
V_{m}=\frac{V_{p}+3 \cdot V_{0,2 h}+2 \cdot V_{0,6 h}+3 \cdot V_{0,8 h}+V_{d}}{10}
$$

where; $h$ is depth of water in meter, $V_{m}$ is mean velocity in $\mathrm{m} / \mathrm{s}, \mathrm{V}_{\mathrm{p}}$ is velocity at the surface in $\mathrm{m} / \mathrm{s}, \mathrm{V}_{0.2 \mathrm{~h}}$ is velocity at water depth $0.2 \mathrm{~h}$ in $\mathrm{m} / \mathrm{s}, \mathrm{V}_{0} .6 \mathrm{~h}$ is velocity at $0.6 \mathrm{~h}$ in $\mathrm{m} / \mathrm{s}, \mathrm{V}_{0.8 \mathrm{~h}}$ is velocity at a $0.8 \mathrm{~h}$ in $\mathrm{m} / \mathrm{s}$ and $\mathrm{V}_{\mathrm{d}}$ is velocity at the bottom in $\mathrm{m} / \mathrm{s}$.

\subsubsection{Head losses and Slope of energy}

Head losses of energy $\left(h_{f}\right)$ is obtained using the energy equation so called Bernoulli equation as explained in [1]. This value is calculated on the basis of water depth in upstream $\left(H_{u}\right)$ and downstream $\left(H_{d}\right)$, and velocity in upstream $\left(V_{u}\right)$ and downstream $\left(V_{d}\right)$. The total head losses of energy then can be formulated as in Equation 6 below.

$$
H_{u}+\frac{V_{u}^{2}}{2 . g}=H_{d}+\frac{V^{2} d}{2 . g}+h_{f}
$$

By solving head losses of energy using Equation 6, then, the slope of energy $\left(S_{f}\right)$ for length of channel L can be determined using Equation 7 below.

$$
S_{f}=\frac{h_{f}}{L}
$$

\subsubsection{The Coefficient of Manning}

By inserting mean velocity $\left(\mathrm{V}_{\mathrm{m}}\right)$ and slope of energy $\left(S_{f}\right)$ in Equation 1 then the Coefficient of Manning can be formulated as in the Equation 8 below.

$$
\mathrm{n}=\frac{1}{\mathrm{~V}_{\mathrm{m}}} \mathrm{R}^{2 / 3} \mathbf{S}_{f}^{1 / 2}
$$

The coefficient of Manning ( $\mathrm{n}$ ) in Equation 8 is the total Coefficient of Manning produced by roughness of channel and vegetation which is equal to Equation 3, where $\mathrm{n}_{4}$ is the same as $n_{v}$ (Coefficient of Manning due to vegetation). In this case Equation 3 is replaced to be Equation 9. By rearranging Equation 9, then the value of $n_{v}$ is obtained using Equation 10. 


$$
\begin{aligned}
& \mathrm{n}=\mathrm{n}_{o}+n_{v} \\
& \mathrm{n}_{\mathrm{v}}=n-\mathrm{n}_{o}
\end{aligned}
$$

\subsubsection{Statistical analysis}

The effect of vegetation height and density on Coefficient of Manning is test using two ways Analysis of variance (Anova) method with the confidence level $(\alpha)$ $=5 \%$ and degree of freedom $(\mathrm{df})=(\mathrm{c}-1, \mathrm{n}-1)$ and $(\mathrm{r}-1, \mathrm{n}-$ 1) to obtain $F$ statistic $\left(F_{\text {stat. }}\right)$ for vegetation height and density respectively. The value of $F$ calculation $\left(\mathrm{F}_{\text {calc }}\right)$ is calculated using Equation 11-14. The procedure and result of Anova is summarized in Table 2.

If $\mathrm{F}_{\text {calc. }}>\mathrm{F}_{\text {stat. }}$ then reject $\mathrm{H}_{0}$, it can be concluded that the vegetation height and density influence the Coefficient of Manning. On the other hand, If $\mathrm{F}_{\text {calc. }}<\mathrm{F}_{\text {stat. }}$ the height and density of vegetation do not influence the Coefficient of Manning.

Table 2. Two-Way Analysis of Variance

\begin{tabular}{|c|c|c|c|c|}
\hline Source & $\begin{array}{c}\text { Sum of } \\
\text { Squares }\end{array}$ & df & $\begin{array}{c}\text { Mean } \\
\text { Square }\end{array}$ & F-Calculation \\
\hline $\begin{array}{c}\text { Vegetation } \\
\text { height }\end{array}$ & SSV & $\mathrm{c}-1$ & $\begin{array}{c}\mathrm{MSV}= \\
\text { SSV/(k-1) }\end{array}$ & MSV/MSE \\
\hline Density & SSD & $\mathrm{r}-1$ & $\begin{array}{c}\mathrm{MSD}= \\
\mathrm{SSD} /(\mathrm{k}-1)\end{array}$ & $\mathrm{MSD} / \mathrm{MSE}$ \\
\hline Error & $\mathrm{SSE}$ & $\mathrm{n}-\mathrm{c}$ & $\begin{array}{c}\mathrm{MSE}= \\
\mathrm{SSE} /(\mathrm{n}-\mathrm{k})\end{array}$ & \\
\hline Total & $\mathrm{SST}$ & $\mathrm{n}-1$ & & \\
\hline
\end{tabular}

Where; $\mathrm{c}$ is number of column, $\mathrm{r}$ is number of row, $\mathrm{n}$ is total of sample, $\mathrm{x}_{\mathrm{ij}}$ is sample in row and column, $\mathrm{T}_{\mathrm{ij}}$ is total sample in row and column, SST is Sum of square total obtained using Equation 11;

$$
S S T=\sum_{i=1}^{k} \sum_{j=1}^{n} x_{i j}^{2}-\frac{T_{i j}{ }^{2} \cdot \cdot}{c r}
$$

SSD is Sum of Square of Density as in Equation 12;

$$
S S D=\frac{\sum_{i=1}^{k} T_{j}^{2}}{c}-\frac{T_{i j}{ }^{2} \cdot .}{c r}
$$

SSV is Sum of Square of Vegetation Height as in Equation 13;

$$
S S V=\frac{\sum_{i=1}^{k} T_{i}^{2}}{r}-\frac{T_{i j}{ }^{2} \cdot .}{c r}
$$

And SSE is Sum of Square of Error as in Equation 14.

$$
S S E=S S T-S S D-S S V
$$

\section{Results and discussions}

\subsection{Mean velocity and its distribution}

The velocity was collected from 3 locations measurement, namely at the upstream, the vegetated zone and downstream, then mean velocity was calculated based on average of 3 locations. The experiments were then repeated with six different densities and heights of vegetation; with fixed water depth in order to maintain fix flow. Based on the measurements of 36 series treatment, the mean velocity distribution is plotted as depicted in Figure 5. As can be seen in the figure that the velocity decrease as increase the density and height of vegetation, or it can be stated that the mean velocity tends to decrease as increase density and height of vegetation. This condition is caused by flow which is blocked by vegetation in the channel, so it cause backwater flow with different direction which make flow resistance is increasing and resulting on decreasing velocity. If compared to un-vegetated channel, the velocity is reducing by $28.68-43.82 \%$. This will effect on flow system in the channel.

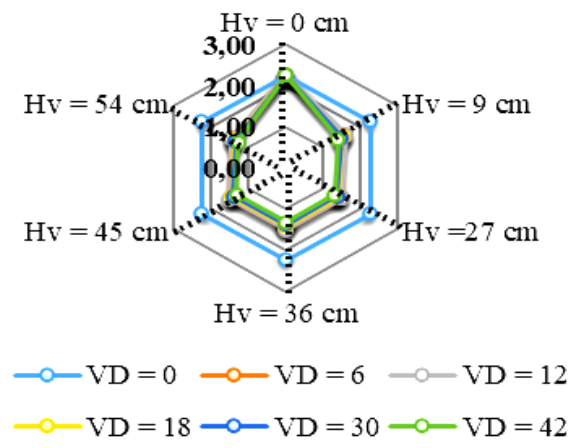

Fig. 5. Mean velocity for various density and height of vegetation

\subsection{The Coefficient of Manning due to density and height of vegetation}

Using Equations 8, after mean velocity $\left(\mathrm{V}_{\mathrm{m}}\right)$ and slope of energy $\left(\mathrm{S}_{\mathrm{f}}\right)$ are analysed, the total Coefficient of Manning (n) can be obtained, as tabulated in Table 3. As you can see in Table 3 that the values of $n$ are in between $0.043-0.064$, which is increasing as increasing density and height of vegetation. Maximum Coefficient of Manning is 0.064 and minimum is 0.043 .

Table 3. Total Coefficient of Manning for various vegetation density and height

\begin{tabular}{|c|c|c|c|c|c|c|}
\hline \multirow{2}{*}{$\begin{array}{c}\text { Vegetatio } \\
\text { n Density }\end{array}$} & \multicolumn{7}{|c|}{ Vegetation height } \\
\cline { 2 - 7 } & $0 \mathrm{~cm}$ & $9 \mathrm{~cm}$ & $\begin{array}{c}27 \\
\mathrm{~cm}\end{array}$ & $\begin{array}{c}36 \\
\mathrm{~cm}\end{array}$ & $\begin{array}{c}45 \\
\mathrm{~cm}\end{array}$ & $\begin{array}{c}54 \\
\mathrm{~cm}\end{array}$ \\
\hline $0 \mathrm{veg} / \mathrm{m}^{2}$ & $\begin{array}{c}0,03 \\
1\end{array}$ & $\begin{array}{c}0,03 \\
1\end{array}$ & $\begin{array}{c}0,03 \\
1\end{array}$ & $\begin{array}{c}0,03 \\
1\end{array}$ & $\begin{array}{c}0,03 \\
1\end{array}$ & $\begin{array}{c}0,03 \\
1\end{array}$ \\
\hline $6 \mathrm{veg} / \mathrm{m}^{2}$ & 0,03 \\
1 & $\begin{array}{c}0,04 \\
3\end{array}$ & $\begin{array}{c}0,04 \\
5\end{array}$ & $\begin{array}{c}0,04 \\
5\end{array}$ & $\begin{array}{c}0,04 \\
8\end{array}$ & $\begin{array}{c}0,05 \\
4\end{array}$ \\
\hline $12 \mathrm{veg} / \mathrm{m}^{2}$ & 0,03 \\
1 & $\begin{array}{c}0,04 \\
3\end{array}$ & $\begin{array}{c}0,04 \\
4\end{array}$ & $\begin{array}{c}0,05 \\
6\end{array}$ & $\begin{array}{c}0,05 \\
5\end{array}$ & $\begin{array}{c}0,06 \\
0\end{array}$ \\
\hline $18 \mathrm{veg} / \mathrm{m}^{2}$ & 0,03 \\
1 & $\begin{array}{c}0,04 \\
7\end{array}$ & $\begin{array}{c}0,05 \\
2\end{array}$ & $\begin{array}{c}0,05 \\
9\end{array}$ & $\begin{array}{c}0,06 \\
0\end{array}$ & $\begin{array}{c}0,06 \\
2\end{array}$ \\
\hline $30 \mathrm{veg} / \mathrm{m}^{2}$ & 0,03 & 0,04 & 0,05 & 0,06 & 0,06 & 0,06 \\
\hline
\end{tabular}




\begin{tabular}{|c|c|c|c|c|c|c|}
\hline & 1 & 8 & 7 & 0 & 0 & 3 \\
\hline $42 \mathrm{veg} / \mathrm{m}^{2}$ & 0,03 & 0,04 & 0,06 & 0,06 & 0,06 & 0,06 \\
2 & 1 & 4 & 2 & 2 & 3 & 4 \\
\hline
\end{tabular}

Meanwhile, the value of Coefficient of Manning for un-vegetated channel $\left(\mathrm{n}_{\mathrm{o}}\right)$ is 0,031 . By using Equation 10 the Coefficient of Manning of vegetation $\left(\mathrm{n}_{\mathrm{v}}\right)$ is obtained in between 0.012-0.034. The Coefficient of Manning of vegetation for different density and height are completely tabulated in Table 4 . In overall there are additional Coefficient of Manning due to combination of density and height of vegetation in the channel by 40 $110 \%$ or 1.4 to 2.1 times if compared to un-vegetated channel. These values are rather similar to previous research of [7] in which there was an additional Coefficient of Manning due to vegetation height by 0.01 0.031 , but the results are only applicable for vegetation density of $45 \mathrm{veg} / \mathrm{m}^{2}$. The similar results are also published by [8] in which Coefficient of Manning of vegetation with various density is found in between $0.011-0.031$, but only applicable for $45 \mathrm{~cm}$ height of vegetation.

Table 4. Vegetated Coefficient of Manning for various vegetation density and height

\begin{tabular}{|c|c|c|c|c|c|c|}
\hline \multirow{2}{*}{$\begin{array}{c}\text { Vegetation } \\
\text { Density }\end{array}$} & \multicolumn{7}{|c|}{ Vegetation height } \\
\cline { 2 - 7 } & $0 \mathrm{~cm}$ & $9 \mathrm{~cm}$ & $\begin{array}{c}27 \\
\mathrm{~cm}\end{array}$ & $\begin{array}{c}36 \\
\mathrm{~cm}\end{array}$ & $\begin{array}{c}45 \\
\mathrm{~cm}\end{array}$ & $\begin{array}{c}54 \\
\mathrm{~cm}\end{array}$ \\
\hline $0 \mathrm{veg} / \mathrm{m}^{2}$ & 0,000 & 0,000 & 0,000 & 0,000 & 0,000 & 0,000 \\
\hline $6 \mathrm{veg} / \mathrm{m}^{2}$ & 0,000 & 0,012 & 0,015 & 0,014 & 0,018 & 0,023 \\
\hline $12 \mathrm{veg} / \mathrm{m}^{2}$ & 0,000 & 0,012 & 0,013 & 0,025 & 0,025 & 0,030 \\
\hline $18 \mathrm{veg} / \mathrm{m}^{2}$ & 0,000 & 0,016 & 0,021 & 0,028 & 0,029 & 0,031 \\
\hline $30 \mathrm{veg} / \mathrm{m}^{2}$ & 0,000 & 0,018 & 0,027 & 0,030 & 0,030 & 0,032 \\
\hline $42 \mathrm{veg} / \mathrm{m}^{2}$ & 0,000 & 0,014 & 0,031 & 0,031 & 0,032 & 0,034 \\
\hline
\end{tabular}

\subsection{The influence of density and height of vegetation on coefficient of Manning}

As mentioned above show that density and height of vegetation influence on coefficient of Manning. At a glance from Figure 6 and Figure 7 can be seen that there is an influence of density and height of vegetation on Coefficient of Manning. Figure 6 explain the relationship between coefficient of Manning and density of vegetation for different height of vegetation.

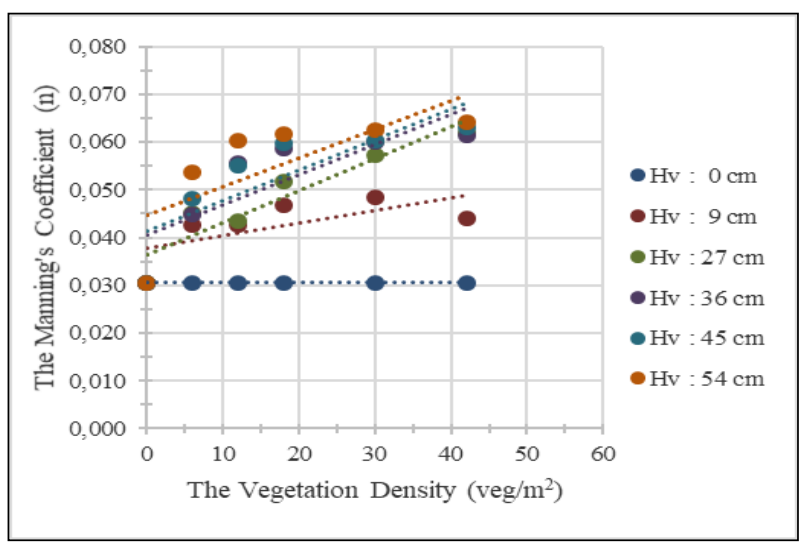

Fig. 6. The effect vegetation density on Coefficient of Manning for various vegetation height.

The figure gives us the information that the trend of graph line tends to be raised when vegetation density and height are increased. The same trend also occurs when we change the relationship between Coefficient of Manning and height of vegetation for different density of vegetation, as in Figure 7. Both figure give us an idea on the effect of vegetation density and height on Coefficient of Manning, but we do not know how much the effect of those variables, therefore it is needed to analyse those effects using statistical analysis test.

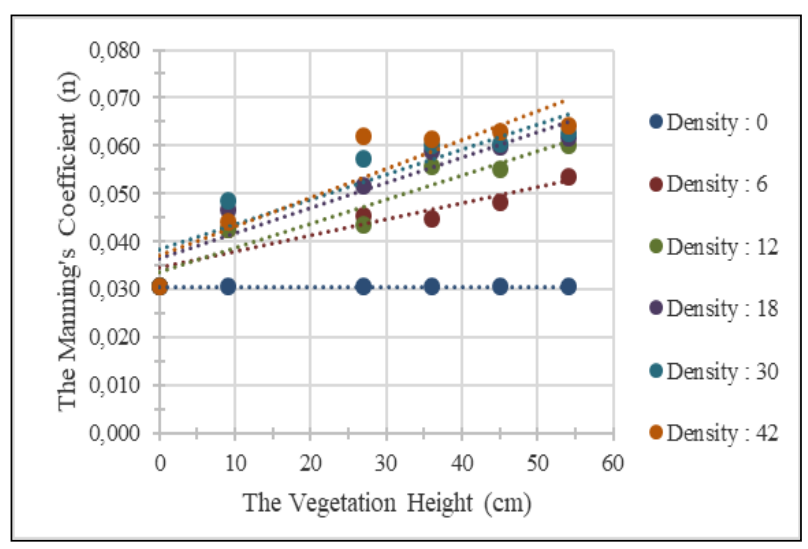

Fig. 7. The effect vegetation height on Coefficient of Manning for various vegetation density

\subsection{Statistical test analysis}

Statistical method of two ways analysis of variance (Anova) is applied to analyse and test the influence of density and height of vegetation on Coefficient of Manning. Based on the procedure described in 3.2.4 above, and using Equation 11-14, it is obtained the result of analysis and test as follows;

Firstly, data collected from the measurements consist of 6 populations of vegetation density $(\mathrm{r}=6)$ and 6 populations of vegetation height $(\mathrm{c}=6)$ and each of them have 6 samples, so total samples $(n)=36$. Using $F$ distribution with confident level $(\alpha)=0.05$ and degree of freedom $\left(v_{1}=(c-1) ; v_{2}=(n-1)\right)=(5 ; 35)$, the value of $\mathrm{F}_{\text {stat }}$ is obtained 2.603 for both density and height of vegetation, since they have the same number of population 
Secondly, data presented in Table 3 or Table 4 is analysed using Equation 11-14 and should be adjusted in respect to the procedure of Anova in Table 2. Then, a summary of the results obtained by the univariate Anova, which reflect the influence of density and height of vegetation on Coefficient of Manning is presented in Table 5.

Table 5. The results of Analysis of Variance Two Ways

\begin{tabular}{|c|c|c|c|c|c|}
\hline $\begin{array}{c}\text { Source of } \\
\text { Variation }\end{array}$ & $\mathbf{S S}$ & $\mathbf{d f}$ & $\mathbf{M S}$ & $\mathbf{F}_{\text {calc }}$ & $\mathbf{F}_{\text {stat }}$ \\
\hline $\begin{array}{c}\text { Vegetation } \\
\text { Density }\end{array}$ & 0,0023 & 5 & 0,00047 & 15,64604 & 2,60299 \\
\hline $\begin{array}{c}\text { Vegetation } \\
\text { Height }\end{array}$ & 0,0025 & 5 & 0,00051 & 16,92760 & 2,60299 \\
\hline Error & 0,0007 & 25 & 0,00003 & & \\
\hline Total & 0,0056 & 35 & & & \\
\hline
\end{tabular}

Table 5 gives the value of $F_{\text {calc. }}=15.646$ for the effect of vegetation density, and $F_{\text {calc. }}=16.928$ for the effect of vegetation height. Since the $F_{\text {Stat. }}$ is lower than $F_{\text {calc. }}$, the null hypothesis was rejected. Therefore, it can be clearly stated that density and height of vegetation are parameters significantly influencing on coefficient of Manning.

we clearly stated that Sweet flag (Acorus Calamus) or Jeringau as local name with various density and height give an effect on the Coefficient of Manning. This information must be entered hydraulically as applicable in the system of network channel, irrigation project or drainage. This should be our concern for operation and management of water resources projects, because the impact of increased resistance to flow due to the presence of vegetation can influence the water balance of water system.

\section{Conclusion}

We can conclude that the presence of Sweet flag (Acorus calamus) with different height and density in the channel can influence the mean velocity. The denser and higher vegetation, the more decreasing of mean velocity in the channel. When compared with un-vegetated channel, and mean velocity become decreasing of $28.68-43.82 \%$. However, on the contrary, the total coefficient of Manning (n) tend to increasing in the range of 0.043 to 0.064 or increase of 1.40 to 2.10 times when compared to the unvegetated channel (where $\mathrm{n}_{0}$ is 0.031). This shows that there is an additional roughness of channel due to the effect of density and height of vegetation $\left(\underline{n}_{\mathrm{v}}\right)$ in between 0,012 to 0,034. In addition, based on analysis of variance, it can be clearly concluded that density and height of vegetation are parameters which strongly influence on the coefficient of Manning.

It would be fruitful to pursue further research by including other characteristics of Sweet flag, such as; diameter of trunk and width of leaf to see the flexibility and rigidity of vegetation so that the roughness of channel due to vegetation can be formulated more accurate.

We would like to show our gratitude to our student and technicians for your contributions during the research activity. We are also immensely grateful to SCESCM'S reviewers for their constructive comments and correction of our manuscript.

\section{References}

1. V.T. Chow, Open-channel hydraulics (McGrawHill, NY), (1959)

2. O.E Hakim and MM. Salama, Velocity distribution inside and above branched flexible roughness J. Irrig. Drain. Eng. 118 914-927 (1992)

3. G.E. Freeman, W.H. Rahmeyer and R.R. Copeland, Determination of resistance due to shrubs and woody vegetation,(Technical Report, ERDC/CHL TR-00-25, U.S.Army Engineer Research and Development Center, Vicksburg, MS, 2000)

4. J. Järvelä, Flow resistance of flexible and stiff vegetation: a flume study with natural vegetation J. Hydrology 269 44-54 (2002)

5. J. Kim, V.Y. Ivanov and N.D. Katopodes, Hydraulic resistance to overland flow on surfaces with partially submerged vegetation Water Resources Res. 48 (2012)

6. M Rizalihadi, Ziana, N. Shaskia and H Asharly, The effect of ratio between rigid vegetation height and water depth on the manning's coefficient in open channel, IOP Conf. Series: Materials Science and Engineering 352 (2018).

7. M. Rizalihadi and M. Ihsan, Pengaruh ketinggian tanaman Pandan Tikar (Acorus Calamus) Terhadap Tahanan Aliran Pada Saluran Terbuka (Prosiding Konferensi Nasional Teknik Sipil 10, Universitas Atmajaya, Yogyakarta, in Indonesian, 2016)

8. M. Rizalihadi and D. Safiana, The presence of Jeringau (Acorus Calamus) as flexible vegetation type in the channel against flow resistance Procedia Engineering 125 250-256 (2015)

9. M. Rizalihadi and D. Afrianti, Kehadiran Rumput Gajah (Pennisetum Purpureum) di saluran terhadap tahanan aliran (Prosiding Konferensi Nasional Teknik Sipil 9, Universitas Hasanuddin, Makassar 267-274, in Indonesien, 2015)

10. T. Tsujimoto, T. Kitamura, Y. Fuji and $H$. Nakagawa, Hydraulic resistance of flow with flexible vegetation in open channel Journal of Hydroscience, Hydraulic Engineering 14 47-56 (1996) 